ANNA MLEKODAJ

Podhalańska Państwowa Wyższa Szkoła Zawodowa w Nowym Targu, Poland

The main topics of the scientific research: linguistics, cultural studies, dialectology, education.

DOI

\title{
VERNACULAR LITERATURE \\ AS A WIDENING FIELD OF \\ STUDY IN CONTEMPORARY \\ DIALECTOLOGY \\ (ON THE EXAMPLE OF \\ PODHALE REGION IN POLAND)
}

\author{
Liaudies literatūra kaip besiplečianti studijų \\ sritis šiuolaikineje dialektologijoje \\ (Lenkijos Podhalès regiono pavyzdys)
}

\section{ANNOTATION}

Dialectal literature was one of the forms of saving the dialect. Despite its distinctive presence in Silesian, Kashubian and Podhalian dialects, both dialectal poetry and epic still remain outside dialectal interest. Focused on phonetics, phonology, syntax and lexis, including pragmatic, cultural and social contexts, dialectal literature has not yet developed its own research tools capable of capturing the essence of this genre. The aim of this article is to indicate the need to extend the research field of modern dialectology to this phenomenon related to the creation of stylistic diversity within the dialect. Dialectal literature is an evident proof of the creation of the artistic-literary variety contained in or found in the dialect. This process was most fully developed in Podhale for various reasons.

KEYWORDS: Polish dialectology, vernacular literature, identity, folklore, Podhale region. 


\section{ANOTACIJA}

Viena iš tarmès išsaugojimo formų - tarminè literatūra. Nepaisant šio reiškinio išskirtinumo Silezijos, Kašubijos ir Podhalès regionų tarmėse, tiek tarminė poezija, tiek epas vis dar nesulaukè tarmių tyrèjų dèmesio. Nors daug dèmesio skiriama fonetikai, fonologijai, sintaksei ir leksikai, taip pat ir pragmatiniams, kultūriniams ir socialiniams kontekstams, dar nèra sukurta tyrimo įrankių, kuriais būtų galima užfiksuoti šio žanro esmę. Šio straipsnio tikslas - pabrěžti poreikị išplèsti moderniosios dialektologijos tyrimų lauką taip, kad jis aprèptų stilistinès ịvairovès kūrimo reiškinį tarmèje. Tarminė literatūra yra akivaizdus meninès-literatūrinès įvairovès kūrimo tarmėje įrodymas. Dèl įvairių priežasčių šis procesas labiausiai pasireiškè Podhalès regione.

ESMINIAI ŽODŽıAI: lenkų dialektologija, tarminè literatūra, tapatybè, tautosaka, Podhalès regionas.

Dialectology describes the lexical and grammatical differentiation of a language. Traditionally, it was combined with the geographical dimension of this phenomenon, and a special focus was made on the speech of the inhabitants of a given village. Nowadays, the field of interest of dialectology also includes urban areas with their rich sociological diversity (Britain 2010: 127-128). The combination of both aspects and directions can define the dialect as a particular form of a language which is peculiar to a specific region or social as well as cultural group.

At the turn between the $19^{\text {th }}$ and the $20^{\text {th }}$ centuries the first research standards of the so-called traditional dialectology were adopted. One of the basic assumptions was the conviction that each dialect is inseparable from a specific defined territory (Auer 2004: 149-150). The purpose of dialectology was therefore to establish the boundary lines between neighboring dialects, analyze the viability of dialectal features in the speech of residents of a given territory (including its center and periphery) and, in view of the progressive changes related to the population's migrations or the structural changes in the region's economic base, identify the core dialectal features in the speech of the inhabitants of a given region (Szmrecsanyi 2014: 81). Traditional dialectology focused mainly on the linguistic characteristics that were then analyzed in terms of their primary and secondary features that distinguished a given dialect against the standard language. The main research area of dialectologists was the living speech of villagers. The most reliable sources were old immobile rural men whose speech was considered the most credible in terms of the representation of certain dialectal features (Britain 2010: 129, Chambers and Reudgill 1998: 29), and the basic research method was a wide-ranging questionnaire-based survey of a dialect focusing on pronunciation or lexis (a survey-based dialectology). This resulted 
Vernacular Literature as a Widening Field of Study

in Contemporary Dialectology (On the Example

of Podhale Region in Poland)

in monumental studies, such as Alexander John Ellis' The Existing Phonology of English Dialects Compared With That of West Saxon Speech (1889). Initiated in the $19^{\text {th }}$ century, the interest in the phonetic and lexical resources of individual dialects together with the possibility of the geographical identification of specific traits contributed to the creation of the atlas of dialects (atlas-based dialectology). This research tradition remains alive. It also has its representation in Polish dialectology (Reichan, Woźniak 2004). Its present continuation can be seen in large projects in the field of dialect-based lexicography for the individual regions of Poland, for example Podhale, Orawa, Lubelszczyzna and Śląsk (Wyderka 2000-2017; Ką́ 2007; Kąś 2015-2018; Pelcowa 2013-2018). The material collected in atlases and dictionaries can be the basis for further research from both synchronic and diachronic perspectives.

Contemporary dialectology is increasingly focused on the creation of dialect corpora, as "principled, possibly computerized, and broadly representative collections of naturalistic spoken (and sometimes written) dialect material" (Anderwald and Szmrecsanyi 2009: 1126). Corpus-based dialectology is not only a source of knowledge about individual dialects in a synchronic and diachronic approach, but it allows for the extensive study in both the disciplines of linguistics and ethnography. An unquestionable advantage of corporal dialectology is the use of broad technological possibilities of the Internet, including the possibility of continually expanding the data resources and the ease of sharing them (Karaś 2015: 83-84). The novelty of corpus-based dialectology is expanding to dialectal written texts. Traditional dialectology was mainly oriented to the spoken language, but it was skeptical about any written form. Meanwhile, as time passes, with the changes taking place in the countryside, the written form is playing an increasingly important role, which will be discussed in this article.

Among dialectal texts, a particular emphasis is attributed to artistic texts, or dialectal literature. While in Western European countries literature in their standard national language was preceded by texts created in dialects (Italy, France), Polish dialectal literature did not know a printed form until the $20^{\text {th }}$ century in Poland. Dialectal literature existed only in those dialects that resisted the intense unification and standardization of the Polish language after the Second World War.

In the frame of the traditional Polish dialectology, researchers embarked into this area for a specific purpose, which dictated the entire research process. If the researchers were interested in analyzing the terminology describing how a certain tool was built or how people performed individual activities (in the area of farming or traditional customs), they focused on this aspect exclusively. The most desirable subject of study was a representative of the older generation remembering old times. The research therefore was primarily concerned with 
gathering the examples of some remnants of the old language, which could no longer give a credible description due to changes in the modern state. In addition, the researcher was usually a stranger from the outside, from a distant land, a scientist usually from the city, who for unknown reasons badgered consistently about some of the local language customs. Having collected the materials, he/she would leave towards an undisclosed location, and never return to share the results of his/her research with the locals in the village. ${ }^{1}$ In addition, local rural schools did not receive any support for activities related to the nurturing of the local dialect. Dialectologists studied dialects while educators fought to extinguish them at the same time.

Such studies were carried out in Poland mainly in the $20^{\text {th }}$ century. These were the times when the dialect was defined as village speech. At that time, people living in the countryside, especially the older ones, did not usually use a different language. Their language was the dialect of necessity, not choice. At that time, in general, the general opinion was that dialects did not inspire respect. They were considered an indicator of low education and social status, and sometimes "backwardness". This kind of stigma determined by a person's speech is not a rare phenomenon, nor is it limited only to the Polish speaking environment. Also, the school system struggled against the dialect, denouncing the students for using it. The implementation of the national standards in language, without there being the ability to practice dialectal bilingualism, was one of the main goals of universal primary education. It was believed that the use of the dialect prevented young people from acquiring higher education and what goes with it, i.e. an improved quality of life. Under these conditions, rural youth eagerly abandoned this part of its heritage. Yet young people, who took over the family farm after completing their education, usually returned to using the dialect to some extent. On the other hand, those who moved to the cities laid it aside completely.

This situation eventually changed radically. In Poland, the witness of dialectal usages was connected with political transformation and subsequent economic changes. A traditional dialect describes the world in which the knowledge about both material and spiritual aspects of life was transmitted from generation to generation. Meanwhile, in recent years, the countryside has radically changed its economic structure. Small farms have become non-profitable. There is a major focus of consolidating pastoral areas into the hands of select farmers, and competition in the marketplace of producing agricultural products

${ }^{1}$ An additional problem was the need to write phonetically thereby taking into account phonological systems and the diversity of different dialects. A dialect in fact functioned only in the oral tradition, thus ruling out the possibility of the text being read by a non-specialist. 
Vernacular Literature as a Widening Field of Study

in Contemporary Dialectology (On the Example

of Podhale Region in Poland)

has forced changes in technology. The former type of a traditional family farm has been superseded by upgraded agricultural companies producing food on a larger scale. This new standardization of reality also brought a new standard language. Dialect was indispensably connected with another world and time based on other principles, and with another system of values.

Yet another important cause weakening the position of the dialect in the countryside has been a fundamental change in broader social communication related to the reconfiguration of culture and, more specifically, with the transition from an analogical phase to a digital phase, related to changes (Hopfinger 2009: 295-297). The wide dissemination of the Internet and social media accelerated the process of language standardization. Also, the globalization of culture gathered pace. Modern schooling no longer attempts to fight dialects, but also does not experience them amongst its students on a daily basis. Rural villages are losing their language and are also losing their identity.

Fortunately, this phenomenon described above does not apply to all areas of Poland. There are regions that nonetheless retain their linguistic and cultural distinctiveness. This happened primarily in the areas where the local dialect and cultural specificity were assigned a very high social value. Such regions are mainly Silesia, Kaszuby, Kurpie, Spisz, Orawa, and Podhale. In each of these regions, there have been different paths utilized to build social conviction of the need to preserve regional identity, including regional speech. Each of these paths could be the subject of a separate article, but for the balance of this article, I will focus on the Podhale region that I know best and from where I come from.

Podhale lies in southern Poland, at the foot of the Tatra Mountains, the highest Polish mountains of Alpine type, belonging to the Carpathian chain. Poor soil and difficult natural conditions contributed to the development of pastoralism. The specific pastoral culture was formed under the strong influence of the Vlachs, who, together with their flocks moved from the Balkan Peninsula through the Carpathian arc to the west. They left traces not only in the general culture, but also in the speech of the Polish highlanders.

For centuries, difficult to access, lost among the mountains and forests, Podhale was isolated from the rest of the country. Flowing from the north, came Polish settlers who received numerous privileges from the kings, cleared the forests, and founded settlements. For centuries, these inhabitants lived in natural isolation, creating an original culture, and preserving their archaic language. It was only in the $19^{\text {th }}$ century that the interested representatives of the intelligentsia came to this corner; they came to the Tatras for research purposes (geologists, geographers and naturalists), and later also because of the climatic benefits to improve their health and leisure. The newcomers discovered exotic half-wild and half-pagan people who were very proud and independent, 
because they never knew slavery or servitude. For this reason, at the turn of the century, the locals became the object of universal fascination and a kind of fashion. Similarly, within the culture of the Tatra highlanders, people noticed the national potential, which would help rebuild the Polish identity after declaring national independence. For this reason, national leaders wanted to surround this culture with comprehensive care and attention. Under the influence of such interest by national leaders, the highlanders themselves appreciated the value of their own culture and decided to protect it, by first calling the Highlanders Association (1904) into existence and later the Polish Highlanders Alliance. Amongst the newly established members of the Alliance there also was an increase in the awareness of the need for education. Many highlanders earned a university degree, and although they could not find work in Podhale, they stimulated the development of its culture.

The tourists visiting from afar were first introduced to the highlander folklore mainly via mountain expeditions. According to the local custom of that time, an expedition into the mountains was accompanied by a company of numerous highland guides, musicians and helpers - porters. Tours usually lasted several days. Evenings by the campfire for guests were filled with highlander tales, music, songs, and dances. Writers were mainly fascinated by highlander tales. The first texts introducing the Podhale dialect were published in 1889 . The first was "Sabala's fairy tale", ${ }^{2}$ which was penned by author Henryk Sienkiewicz who was later awarded the Nobel Prize in Literature.

At the beginning of the $20^{\text {th }}$ century another famous Polish writer, Kazimierz Tetmajer, created a series of stories From the Rocky Podhale (1914), with most of the pieces written in the language of stylized Podhale dialect. While Sienkiewicz had no prior connections with Podhale, Tetmajer himself was born and spent the first 8 years of his life there. He knew the dialect and understood it, but it was not his native tongue, since he came from a noble family, and not from a highlander family. For this reason, neither "Sabala's fairy tale" nor the stories from Tetmajer can be considered authentic dialectal texts. They are the only examples of stylizations or artistic improvisations of the dialect.

With the formation of an indigenous segment of educated highlanders who were very much involved in the movement of regional identity, they went on a crusade to form regional literary work. Native highlanders from Podhale started writing their own verses in their indigenous language or dialect. The first of them was Andrew Stopka, a native mountaineer from the village of Koscielisko at the foot of Zakopane, who transcribed many tales of Sabala - his neighbor.

2 Sabala is the nickname of the famous highland storyteller John Krzeptowski (1809-1894), who became an icon of the Podhale highlands. 
Vernacular Literature as a Widening Field of Study

in Contemporary Dialectology (On the Example

of Podhale Region in Poland)

Stopka is also the author of an original dialectal text, which developed the theme of the knights sleeping in the Tatra Mountains. Both texts were written and published at the end of the $19^{\text {th }}$ century. For today's researchers of the highlanders' dialect, ${ }^{3}$ Stopka's writings are a reliable source of knowledge about the form of the dialect of his time, even though they have undoubtedly a high artistic flourish, and the dialect used in them presents a slightly different form than that used in everyday speech. A similar conclusion can be reached about the writings of another educated highlander from Zakopane - Wojciech Brzega who published a volume of short stories written in the dialect entitled Posiady. Stories from Podhale (1913) at the beginning of the $20^{\text {th }}$ century. Being a native highlander, Brzega used his first language or dialect. Both for Stopka and Brzega the dialect was their first, natural language, with the Polish standard language learned much later (and probably with difficulty) as a result of their school and university education. Their work laid the foundations for the Podhale regional writing, and the dialect from the Tatra was already living to see its own literature. Before the Second World War, three volumes of self-published poetry in the highlander dialect (Anthony Zachemski Geśle z jawora in 1935, Stanislaw Nedza-Kubinec Na nowa perć in 1936 and Jan Mazur Z wysokik Tater wiaterny sum in 1937) showed up. Additional poems in the highlander dialect appeared in the press in both regional and national publications. In 1937, the anthology entitled Poezja mlodego Podhala was compiled at the Jagiellonian University in Krakow. It concentrated on presenting the writings of young highlander authors, who wrote in the dialect. Both university graduates and self-taught highlanders, women and men, were among the authors; with the exception of one woman, they were all born in highlander families in Podhale, and the dialect was their first language. Only Anna Nowobielska did not originate from Podhale; however, she arrived there with her mother-teacher at the age of two years and spent her childhood among the highlander children, which shaped her speech and views of the world. During her entire life Nowobielska wrote poems in the dialect (she died in 1992) and became a widely known highlander poet.

Influenced by the newcomers from other regions of Poland, the Tatra literary movement launched in the in the $20^{\text {th }}$ century progressed continuously radiating influence into neighboring regions. Today, we can already talk about the five generations of native Tatra highlanders writing and publishing their poems and prose in the Podhale dialect. This literature disseminated widely amongst numerous highlander audiences. Due to the fact that the Tatra dialect as the dialect of the Polish language is not difficult to understand by an average Pole,

${ }^{3}$ I mean first of all Joseph Kąś, author of the monumental work Illustrated Lexicon of Dialect and Culture of Podhale (published in seven different volumes since 2015). 
and its spelling ${ }^{4}$ refers to the Polish orthography, the literature of the dialect is a great source to get to know the mentality of Podhale Highlanders and the world in which they live.

Two main trends emerged at the early stage of the dialect development in Podhale literature. The first developed in close connection with the traditions of the local folklore, referring, from the perspective of prose, to a folk fairy tale called godka in Podhale, and to folk songs from the perspective of poetry. These references are both thematic and formal. The four-verse rhyme is typical of Podhale and has set the basic shape of the highlander poetry. Also, in the scope of the presented content, this trend is a continuation of traditional folklore motifs and threads.

The second trend is set by artists inspired by the achievements of contemporary Polish prose and poetry, from which they mainly draw their inspirations. This particularly applies to poets with higher education who are aware of their poetic technique. Their work is aimed at broadening the dialect with the possibility of expressing the content that they have not touched regularly on a daily basis. We also owe them for their interesting dialectal imagery, thanks to which it has become possible to capture the content that goes beyond the everyday experience of living in a highlander village.

Paradoxically, due to this creative work, dialectal poetry often remains beyond the interest of dialectology, which is mainly focused on the description of a defined stable system in which language is a direct reflection of reality. The dialectal output, and mainly the poetry of this non-folk trend, creates an area of dialect to which appropriate research tools should be created.

There are several reasons why dialectal writing, especially the poetry beyond the folkloric trend, is not regarded as a good source of knowledge by most

${ }^{4}$ The spelling of the Podhale dialect is a different issue. According to the classical approach, the dialect is a living speech devoid of texts. This condition still applies to many other Polish dialects. That is why, dialectologists have used phonetic records. This type of record, however, is hermetic, and the ability to use it is usually limited to a narrow environment of linguists. For the poet who writes in the highlander dialect, Polish has become the basis of transcription. Initially, some common signs were introduced, which were supposed to distinguish a different implementation of individual sounds, but with time, this was given up on the common understanding of the community. The orthography of the Podhale dialect is still neither stabilized nor universally defined. Each author writes as he/she thinks appropriate. Usually, however, this approach does not interfere with the identification of the dialect. The creation of a written variation of a given language is a long-term process. Meanwhile, the longest literary traditions which we have in the case of Podhale are only 120 years old. Perhaps, as a result of the further development of literature in this region, a uniform spelling will be created. To a large extent, this may come to pass due to the emerging work Illustrated Lexicon of Dialect and Culture of Podhale by Prof. Józef Kąś. Due to the author's authority, the spelling or orthography used in it may become the norm over time. 
dialectologists. The most important of them is related to the author's individual approach to language. Some dialectologists believe that the author's poem may also give his/her own vision of the dialect. It can, for example, strengthen some of its features and weaken others. His/her dialect may have the character of the projection or an individual vision rooted in that individual's experience of the past. In this dimension, the dialect can escape the image formed from the basis of the tools used thus far. However, if we treat the dialectal artistic creation as one of the forms of life in the dialect, its insightful analysis could provide a lot of valuable information about the individualization of dialectal expression or intra-stylized stylization. The dialect, like any language, has the right to create within its scope various kinds of varieties, some of which will give evidence to the general language system, while others about its internal stylistic derivations. Dialectal literature is one of them.

Another reason is the conviction that the dialectal literature of the nonfolkloric trend is a phenomenon essentially strange to the dialect - in a sense unnatural. It is usually associated with the creation of the vision of the world that is not compatible with the traditional folklore recorded in the texts. It introduces a different perspective of looking at reality, breaking down the existing stereotypes. It is a kind of implementation that escapes the previous rules of description. However, it is quite risky to ignore this form of linguistic activity just because it does not fit into the complete vision of the dialect as a whole. Nowadays, we observe a widespread departure from the dialect in the everyday speech of the village (also in Podhale). Yet, at the same time, dialectal literature is still developing. New volumes of poems are published; authors use Standard Polish daily, while remaining faithful to it in written poetry. Over time, literature can become an important, if not the only, area of dialectal life. Therefore, today we should learn to take it seriously and learn from it about the role and place of the dialect in the modern world.

\section{REFERENCES}

Anderwald Lieselotte, Szmrecsanyi Benedikt 2009: Corpus Linguistics and Dialectology. - Handbooks of Linguistics and Communication Science, Lüdeling Anke, Kytö Merja (eds). Walter de Gruyter. Berlin / New York, 1126-1139.

Auer Peter 2004: Sprache, Grenze, Raum. - Zeitschrift für Sprachwissenschaft 23, 149-179.

Bielatowicz Jan 1937: Poezja młodego Podhala. Kraków: Koło Naukowe Polonistów UJ.

Britain David 2010: Dialectology. - Encyclopedia of Linguistics, ed. Malmkjaer Kirsten. London, Routledge. 
Brzega Wojciech 1913: Posiady. Opowiadania z Podhala. Kraków: Księgarnia Literacka.

Chambers Jack K., Trudgill Peter 1998: Dialectology. Cambridge: Cambridge University Press.

Hpofinger Maryla 2009: Rekonfiguracja komunikacji społecznej. - Przegląd Filozoficzno-Literacki 4(25), 393-402.

Karaś Halina 2015: Zadania dialektologii w zakresie ochrony ginących gwar. Gwary Dziś 7, 83-95.

Kąś Józef 2003: Słownik gwary orawskiej. Kraków: Wydawnictwo Akademickie.

Kąś Józef 2015-2018: Ilustrowany leksykon gwary i kultury Podhala, Bukowina Tatrzańska. Nowy Sącz: Bukowiańskie Centrum Kultury (t. I-III), Małopolskie Centrum Kultury Sokół (t. IV-VII).

Mazur Jan 1937: Z wysokik Tater wiaterny sum. Lwów: Książnica Atlas.

Mlekodaj Anna 2015: Kwietno Pani. O gwarowej poezji Podhala w ujęciu kulturowym. Rabka Zdrój: Wydawnictwo „Zachylina”.

Mlekodaj Anna 2014: O literackim potencjale gwary podhalańskiej. - Badania dialektologiczne. Stan, perspektywy, metodologia, eds. Sikora Kazimierz, Rak Maciej. Kraków: Księgarnia Akademicka, 181-200.

Nędza-Kubiniec Stanisław 1936: Na nowa perć. Kościelisko: Związek Podhalan. Zachemski Antoni 1935: Gęśle z jawora. Kraków: Krakowskie Ognisko Związku Podhalan.

Pelcowa Halina 2012-2018: Słownik gwar Lubelszczyzny. Lublin: Wydawnictwo UMCS.

Przerwa-Tetmajer Kazimierz 1914: Na Skalnym Podhalu. Kraków: Wydawnictwo Literackie.

Reichan Jerzy, Woźniak Kazimierz 2004: Polskie atlasy dialektologiczne $i$ etnograficzne. Kraków: Wydawnictwo Lexis.

Sienkiewicz Henryk 1889: Sabalowa bajka. - Czas 170(XLII), 1.

Szmrecsanyi Benedikt 2014: Methods and Objectives in Contemporary Dialectology. - Slavica Bergensia 12, 81-92.

Wyderka Bogusław 2000-2017: Słownik gwar śląskich (vol. I-XVI). Opole: Silesia Progress. 
Vernacular Literature as a Widening Field of Study

in Contemporary Dialectology (On the Example

of Podhale Region in Poland)

\section{Liaudies literatūra kaip besiplečianti studijų sritis šiuolaikinejje dialektologijoje (Lenkijos Podhalès regiono pavyzdys)}

\section{SANTRAUKA}

Straipsnyje pabrèžiamas dialektologijos mokslo tyrimų objekto (tam tikrų kaimo vietovių gyventojų kalbos studijų) pokytis, apimantis ir miestų teritorijas su joms būdinga sociologine įvairove. Tai apibūdina dialektą kaip savotišką tam tikram regionui ar socialinei ir kultūrinei grupei būdingą kalbos formą. Be to, aptariama istorinės tradicinès dialektologijos, kurios pagrindinis tyrimo objektas buvo gyvoji kaimo gyventojų kalba (fonetiniai ir leksiniai atskirų dialektų resursai), raida; minimi pagrindiniai tyrimų metodai, tarkim, plačios apimties klausimynai, kuriuos naudojant buvo siekiama ištirti tam tikro dialekto fonetinius ir leksinius ypatumus; remiamasi esminiais darbais. Svarbiausias dėmesys skiriamas šiuolaikinei dialektologijai (korpuso / tekstynų dialektologijai), kurios tikslas - surinkti didelès apimties natūralios (gyvosios) šnekamosios (kartais rašytinès) kalbos medžiagą, leisiančią atlikti sinchroninius ir diachroninius atskirų dialektų tyrimus, praplečiant juos nuo vien tik šnekamosios kalbos studijų iki tarmiškai parašytų tekstų analizės. Toki dialektologijos tyrimų apimtic (bent jau Lenkijoje) lèmė politiniai, ekonominiai ir kultūriniai pokyčiai, kitaip tariant, globalizacijos procesai visose žmogaus gyvenimo srityse. Tai susilpnino tarmiu pozicijas kaimo vietovėse. Nors globalizacijos procesai vyksta visoje Lenkijoje, šalyje vis dar liko šiais procesais nepaveiktų vietovių, išsaugojusių savo kalbinị bei kultūrinị savitumą (ypač regionuose, kur vietinè tarmė ir kultūra ịgijo ypatingą socialinę vertę), - tai Silezija, Kašubai, Kurpiai, Spišas, Orava ir Podhalè. Visi išvardyti regionai išsaugojo savo tapatumą, įskaitant tarmes.

Nors kiekvienas iš minètų regionų yra unikalus ir vertas dėmesio, atliekant tyrimą buvo pasirinktas Podhalès regionas (pasirinkimą lèmé asmeniniai motyvai). Straipsnyje aprašomos pasirinkto regiono geografinès sąlygos, lèmusios kultūros savitumą ir istorinę raidą; minimas šalies lyderių susidomėjimas regionu, dẻl ko 1904 m. buvo ikurta Lenkijos kalniečių asociacija, taip pat turistų susidomėjimas regionu, jo gyventojais ir kultūra (ypač tautosaka). Atkreipiamas dėmesys ị pirmuosius tekstus, parašytus Podhalès tarme, - tai Henriko Sinkievičiaus Sabolos pasaka (1889) ir Kazimiežo Tatmajerio istoriju serija Iš uolingos Podhalès (1914). Taip pat minimi kiti Podhalès autoriai (vietiniai gyventojai), rašę šio regiono tarme, tarp kurių Andžejus Stopka, Vojciechas Brzega, Antonis Zachemskis ir kt. Aprašomos iš šių autorių kūrybos kilusios liaudies literatūros pagrindinès kryptys. Pirmoji kryptis - literatūriniai kūriniai, kuriuos parašyti ịkvėpė Podhalès folkloro (pasakų ir dainų) motyvas; antroji kryptis - autorių kūriniai, kuriuos sukurti paskatino šiuolaikinė lenkų literatūra. Tačiau tarminè poezija iki šiol neatkreipẻ dialektologų dėmesio. Išvardijamos priežastys, dèl kurių kūriniai, parašyti tarmiškai, nesulaukia dialektologų dėmesio. Pagrindinė jų - autoriaus subjektyvus požiūris ị kalbą. Konstatuojama, kad ilgainiui liaudies literatūra 
taps labai svarbi tarmès gyvavimo paskata, todẻl jau šiandien ị ją atkreiptinas ypatingas dèmesys, nes per liaudies literatūrą atsiskleidžia tarmès vieta šiuolaikiniame pasaulyje.

Itteikta $2018 \mathrm{~m}$. spalio $2 \mathrm{~d}$.

\author{
ANNA MLEKODAJ \\ Podhalańska Państwowa Wyższa Szkoła Zawodowa \\ w Nowym Targu, Poland \\ Ul. Bystra 8, 34-700 Rabka-Zdroj, Poland \\ qaz10@poczta.onet.pl
}

